\title{
Building open access in Africa
}

\author{
Williams E. Nwagwu
}

Africa Regional Center for Information Science (ARCIS)

6 Benue Rd., P.O. Box 22133 UIPO

University of Ibadan, Nigeria

\author{
Allam Ahmed* \\ SPRU - Science and Technology Policy Research \\ The Freeman Centre, University of Sussex \\ Brighton BN1 9QE, UK \\ Fax: +44 (0) 1273685865 \\ E-mail: allam.ahmed@sussex.ac.uk \\ *Corresponding author
}

\begin{abstract}
Developing Countries (DCs), particularly those in Sub-Saharan Africa (SSA), are suffering from scientific information famine. The expectation that the internet would facilitate scientific information flow does not seem to be realisable, owing to the restrictive subscription fees of the high quality sources and the beleaguering inequity in the access and use of the internet and other Information and Communication Technology (ICT) resources. This paper aims to assess and evaluate Open Access (OA) movement as a proposed solution to avoid the restrictions over accessing scientific knowledge, particularly in SSA. The paper also outlines the opportunities and challenges in implementing OA in SSA. However, there are often mismatches between what the 'donor' countries can reasonably offer and what the SSA countries can implement. Finally, the paper will discuss the slow uptake of the OA in Africa, the perception of the African scientists towards the movement, the non-expression of concern by policymakers and their implications on the scientific activities in Africa.
\end{abstract}

Keywords: Open Access; OA; open source; digital divide; Information and Communication Technologies; ICTs; Developing Countries; DCs; Sub-Saharan Africa; SSA; information; copyright; copyleft; open content.

Reference to this paper should be made as follows: Nwagwu, W.E. and Ahmed, A. (2009) 'Building open access in Africa', Int. J. Technology Management, Vol. 45, Nos. 1/2, pp.82-101.

Biographical notes: Williams E. Nwagwu is a Lecturer at the Africa Regional Centre for Information Science (ARCIS), University of Ibadan, Nigeria. He specialises in Health/Biomedical Informetrics and other aspects of quantitative applications in Information Science. Currently, issues relating to the digital divide, with particular respect to the imbalance in electronic literature control activities of the developed countries and their impact on the status of science in the developing regions, dominate his research interest.

Allam Ahmed holds a $\mathrm{PhD}$ in Technology Transfer with backgrounds in Economics, Management and Marketing. He is a Full Member and Chartered Marketer of the Chartered Institute of Marketing, UK. Ahmed is the Founding 
Editor of the WRSTSD, WREMSD and IJFSNPH and serves on the editorial board of five international journals in Business, Enterpreprenurship, Marketing, Management, Strategy and International Business. He has substantial experience in research and teaching in Africa, Europe and the Middle East. Ahmed is the Founding President of the World Association for Sustainable Development (WASD) and has consulted for several leading public and private institutions and worked with international organisations.

\section{Introduction}

Many scholars such as Danofsky (2005), Hamel (2005) and Mansell and When (1998) argue that information can lead to knowledge and knowledge is a prerequisite for development (also see Ahmed and Nwagwu, 2006). UNESCO's 32nd General Conference in 2003 focused on 'Building Knowledge Societies and advancement of knowledge-based practices' as an essential component of globalisation and sustainable economic growth, particularly in Developing Countries (DCs). Therefore, Information and Communication Technologies (ICTs) can play an important role in accelerating the development process in most DCs, particularly Africa. Yet, according to the United Nations (Danofsky, 2005), millions of people in Africa have never made a telephone call and without the ability to communicate, Africa will remain poor and isolated, lacking the means to participate in the global society. Moreover, education and knowledge are the chief currencies and the essence of the modern age and can also be a strategic resource and a lifeline for the DCs' sustainable development (Hamel, 2005; Juma, 2003).

Technological innovation in ICTs and the liberalisation of the regulatory context of the media and telecommunications sectors have profoundly changed the global communications landscape (Nulens et al., 2001). And although these changes have originally started in the developed countries, they also offer great opportunities for the DCs. Early 2005, the UN announced the launch of the 'Digital Solidarity Fund' to finance projects that address the uneven distribution and use of ICTs to enable poor people enter the new era of the information society.

Governments spend vast amounts on scientific research; yet, the majority of the articles reporting the results of this valuable investment is locked in archives, which only give access to paying subscribers. As a result, restricting access to knowledge restricts the development of science and has severe effects on the general well-being of people. Whilst libraries in the developed world are struggling to purchase access to all the scientific publications they need, subscriptions are prohibitively expensive for institutions in the developing world, particularly SSA. This could eventually lead to an increasing marginalisation of science and scientists in poorer countries, with a growing gulf in technological proficiency and economic development between the rich and poor. Therefore, the challenge of how to foster the global free flow of scientific publications should be a matter of serious interest to scientists, their institutions and governments. As a matter of fact, scientists all over the world constitute a single community of people working together to solve human problems and therefore require access to each other's research results (De Solla Price, 1963; Merton, 1973; Mengxiong, 1993). A recent example of how knowledge sharing can accelerate development in science and benefit 
people has been experienced in the case of Severe Acute Respiratory Syndrome (SARS) epidemic, during which the Human Genome Project data was made available to scientists to turn a collection of individual sequences into an incomparably richer resource (see PLoS for more details).

According to Professor Peter Suber's Timeline of the Open Access (OA) movement, the international movement of open access started in 1966 and since then, the movement towards open access has been going from strength to strength and even the UN World Summit on the Information Society (2003) endorses open access in its declaration of principles and plan of action.

The purpose of this paper is to assess and evaluate $\mathrm{OA}$ as a proposed solution to avoid the restrictions over accessing scientific knowledge, particularly in the developing countries and therefore bridging the digital divide. Given the current poor conditions and isolation of developing countries from the rest of the world, a number of fundamental research questions are addressed:

- What are the consequences of poor ICT infrastructure in developing countries?

- To what extent are stakeholders in the development field responsive to the current needs of connecting developing countries to the global society?

- How Good is Open Access for Africa? How do we build OA in Africa?

- What are the opportunities and challenges of Open Access for Africa?

- What are the policy implications of the answers to the above-stated questions?

\section{The digital divide}

It is estimated that over the next decade, $30 \%$ of the world's economic growth and $40 \%$ of all new jobs will be IT driven (Vinay and Saran, 1998). Today, countries are increasingly judged by whether they are information-rich or information-poor. For SSA countries, keeping up with these changes, and involvement in research, are both vital. African countries recognise that much of their economic future will depend upon the understanding of the global technological forces at work and their long-term implications. However, the evidence also shows that the benefits accrued from the utilisation of ICTs over the recent years have been inequitably distributed with SSA countries facing the prospect of being marginalised. This marginalisation has afflicted a new form of poverty, information poverty, within these countries. The world is beginning to divide between the information rich and the information poor nations (see Ahmed, 2004). Walsham (2000) argues that the industrialised countries of the world have been the dominant in the production, development and transfer of information technology, and their interest in the use of IT/S in the DCs has often been more concerned with the profitability of their own business enterprises than with any broader goals concerning the development of the receipt countries. Therefore DCs are posed with the challenge of either becoming an integral part of the knowledge-based global culture or face the very real danger of finding themselves on the wrong side of the digital divide. 


\section{So what does the term 'Digital Divide' really mean?}

The 'Digital Divide' can simply be defined as the invisible border, that separates those who can afford ICTs and those who can not and could therefore have far-reaching consequences (for more discussion see Ahmed, 2004; Nulens et al., 2001; Marcelle, 2004; Mansell and When, 1998; Walsham, 2000). By digital divide, we refer to inequalities in access to the internet, extent of use, knowledge of search strategies, quality of technical connections and social support, ability to evaluate the quality of information, and diversity of uses (DiMaggio et al., 2001). Moreover, in the developed countries, there is a rapidly growing literature on the potential of innovative ICTs applications and on the organisational, social, political, and economic conditions that are likely to support their effective use (see Dutton, 1997; 1999; Mansell and When, 1998). However, unlike the situation in the developed countries, there is also a growing literature in the DCs but it is more fragmented, and often restricted to sector applications or to country specific interests. It is therefore difficult for decision-makers in DCs to access systematic information about the potential applications that are being developed and implemented and to consider how they could be applied to meet their own development needs.

The digital-divide underpins much of the ongoing discourse on whether ICT can be harnessed for mitigating poverty in DCs with several voices arguing that those who live on less than $\$ 1$ a day have no need for ICTs. The proponents of ICTs on the other hand however consider ICTs as tools that can be used to provide the poor economic opportunity and improvement in human well-being (see World Bank, 2001; UNCTAD, 2003).

Furthermore, the new ICT products and applications are frequently designed in ignorance of DCs' realities particularly SSA and fail to address the needs of the most disadvantaged sections of the community (Mansell and When, 1998). As pointed out by Arunachallam (2002), the gulf in the levels of science and technology between the developed and the DCs will tend to widen further with the rapid expansion of the internet in the West and the speedy transition to electronic publishing, and this can lead to increased brain drain and dependence on foreign aid of a different kind (knowledge imperialism). Castells (1998) provides evidence and argues that the use of IT in the DCs is deeply implicated in the processes of social exclusion and that the 'fourth world', defined as including the areas of social deprivation in the DCs, is increasing in size. The risks for DCs are greater simply because they are less developed and are faced with the prospect of having to integrate advanced technologies while their economic development and infrastructure is not yet mature. The workers in these countries are susceptible to greater vulnerability as a result.

In most SSA countries there is less than one line for every 100 inhabitants with a 3.5 years average waiting time for a telephone connection (World Bank, 2000a-b; 2001; 2003a-b; 2004; 2005). Internet connectivity in tertiary education institutions in Africa is in general too expensive, poorly managed and inadequate to meet even basic requirements. As the recent Africa Tertiary Institutions Connectivity Survey (ATICS) survey by the African Virtual University (Figure 1) showed, the average African university has bandwidth capacity equivalent to a broadband residential connection available in Europe, pays 50 times more for their bandwidth than their educational counterparts in the rest of the world, and fails to monitor, let alone manage, the existing bandwidth (ATICS, 2005). As a result, what little bandwidth that is available becomes even less useful for research and education purposes. However it is important to note 
Wilson's distinction (cited in DiMaggio et al., 2001) between formal access (physical availability) and effective access (affordable connectivity and diffusion of skills people need to benefit from technology).

Figure 1 Average bandwidth costs/kbps by region (see online version for colours)

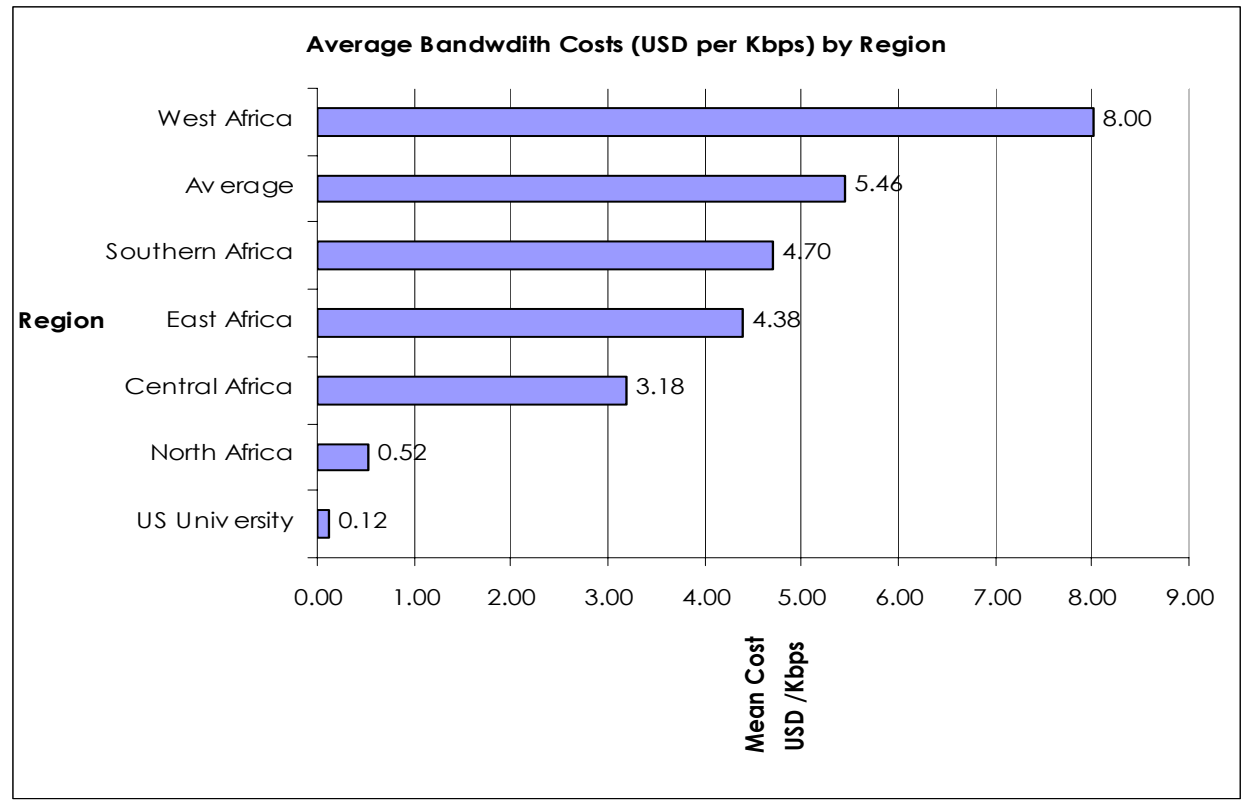

Source: ATICS (2005)

Also the Bandwidth ${ }^{1}$ availability in SSA varies tremendously but is generally very low. If high-bandwidth internet access is not widely available in universities, companies as well as individual homes, the ability to participate in open access activities is severely limited. Therefore accessability to the worldwide network is not surprisingly very low in most SSA countries (see Table 1).

Table 1 Internet users (per 1000 people) people with access to the worldwide network

\begin{tabular}{lc}
\hline World regions & Internet users (2002) \\
\hline Sub-Saharan Africa & 9.6 \\
South Asia & 14.9 \\
Arab States & 28 \\
East Asia and the Pacific & 60.9 \\
Latin America and the Caribbean & 81.2 \\
All DCs & 40.9 \\
Central and Eastern Europe & 71.8 \\
OCED & 383.1 \\
High-income OCED & 450.5 \\
World & 99.4 \\
\hline
\end{tabular}

Source: UNDP (2004) 
Anyimadu (2003) argues that the new ICT applications are frequently designed without considering the social and environmental realities of the DCs. The gulf in the levels of ICT between the developed and the DCs will tend to widen further with the rapid expansion of the internet in the West and the speedy transition to electronic publishing, and this can lead to increased brain drain and dependence on foreign aid of different kinds (see Arunachallam, 2002). Indeed, for many scholars, electronic publication has failed to address the problem of accessibility: one of its promises, lower costs (irrespective of who has to pay for them in the end), is simply not happening fast. There are strong indications, in fact, that consumers - scholars, their libraries, and their institutions - are paying for the development of electronic versions of scholarly information (Create Change, 2000). However a recent report by the UK House of Commons Science and Technology Committee (STC) (2004) entitled Scientific Publications: Free for all?, argues rather different opinion regarding these issues of poor ICT in DCs and highlights the need for further development of ICT capacity to fully exploit the potential of digital technologies. According to Sir Crispin Davis (STC, 2004) the movement to a digital-only environment would have the result of reducing accessibility to scientific research because it is only available on the internet and globally it would exclude over $50 \%$ of scientists.

\section{OA movement}

In the recent years, there has been an increasing agitation by scientists, demanding that scientific publications be freed from the control of the commercial publisher. In this part of the article, we discuss some of these developments, which we have deliberately crammed together as OA. The missions of these initiatives include, among others, advocating that scientific publications be excluded from copyright protection and that scientific papers be made available to scientists and other users free of charge. Typical examples of these initiatives include copyleft, open content (also open access publishing) and open source knowledge (software). We are exploring these initiatives with a view to understand their potentials as well as the challenges they face regarding improving the poor standing of Africa in the current global scientific information chain.

\subsection{Copyright}

The current structure and practice of copyright, with respect to its tight grip of scientific publications, have made the concept look misleading, copyright was actually well intended. Copyright was instituted to protect the owner ${ }^{2}$ of an intellectual property, but it is today a bug business. With respect to scientific publications, however, the copyright protection as presently practiced is somewhat incestuous. This is because the property right of an article for which a scientist could be promoted to the rank of professorship, for instance, developed probably from the rigours of formal science, involving sometimes huge cost, laboratory experiments, and possibly funded by an agency, and so on. Although the scientist might be too busy to be a guardian of this publication, the popularity of the scientist and what is known about him and his works depend on how widespread his ideas are. Usually, a scientist regards this symbolic credit as a worthwhile benefit, and this might be the sole credit for which he embarks upon the scientific 
activity. Meanwhile the free materials received from the scientists by the publisher do not translate to reduced journal prices for the audience for which the scientist has written his article; neither does it guarantee free subscription by scientists and libraries to enhance the wide reach of the articles to those who need them. This right of ownership of the articles is sold to the publisher at no cost without the publisher even increasing complimentary copies to deserving persons. Rather, scientists are used merely to improve the worth of the articles written by their counterparts; the articles are then sold back in form of journals and other packages to the institution, which probably sponsored the same research. In a world in which access to wealth is uneven, scientists from the developed world would have better access to scientific information than their counterpart in the developing regions, and this is the situation at present.

\subsection{Copyleft}

Copyleft is a 'mockery' of copyright. In its original use, it is a general method for making a scientific publication free, and requiring all modified and extended versions of it to be made available freely as well. People are allowed to share the work and their improvements, if they are so minded. Users can make changes, and distribute the result as a proprietary product. It therefore contributes in the advocacy for the abrogation of all copyright issues that tend to prevent a free flow of scientific publications. Copyleft actually developed from the Open Source software and Free Software Foundation (FSF) during the early days of the internet (Stallman, 1999). The concept of 'free' in FSF usage is as in 'free speech' and not as in 'free beer'. Hence freedom is restricted to use, modification, and distribution and not cost. Gradually open source documents, which developed as a result of the need to provide documentation to Open Source software is becoming very popular in the USA and UK (Moller, 2004). Beginning with the Frequently Asked Questions (FAQ) in which users of the Open Source software are given the opportunity to inquire from the software providers about how to use the software they supplied, and solve problems that arise in the course of using the software have become gradually more available. This has also sprawled the development of the concept of the open content.

\subsection{Open content (OA publishing)}

Content is often defined as anything that is not a computer programme, but can be recorded or stored and reproduced digitally such as scientific publications. Open content would then imply an unrestricted access to content. The idea of Open Content ${ }^{3}$ is about distributing learning materials for free, but ensuring that the copyright remained with the authors and that the article would be used responsibly (Wiley, 1999). This process will therefore facilitate the prolific creation, of freely available, high quality well-maintained content. This content can be used in infinity of ways restricted only by the imagination of the user. The idea of Open Content then led to the development of an Open Content License, commonly known as OPen Publication License (OPbL), which is one of a number of small related legal instruments for promoting free and open distribution of knowledge. With this license, anyone can modify, use, and distribute or even sell an object published in according to the OPbL, observing certain restrictions.

OA Publication is defined by the Bethesda Meeting on OA Publishing (11 April 2003) as one that meets the following two conditions: 
1 The author(s) and copyright holder(s) grant(s) to all users a free, irrevocable, worldwide, perpetual right of access to, and a license to copy, use, distribute, transmit and display the work publicly and to make and distribute derivative works, in any digital medium for any responsible purpose, subject to proper attribution of authorship, as well as the right to make small numbers of printed copies for their personal use.

2 A complete version of the work and all supplemental materials, including a copy of the permission as stated above, in a suitable standard electronic format is deposited immediately upon initial publication in at least one online repository that is supported by an academic institution, scholarly society, government agency, or other well-established organisation that seeks to enable open access, unrestricted distribution, interoperability, and long-term archiving (for the biomedical sciences, PubMed Central is such a repository).

In this definition, the idea that dissemination of scientific discoveries and ideas provides the further foundation for progress in science makes the model justifiable from a community point of view. In addition, it can be easily argued that removing barriers in front of access to knowledge will provide further benefits for the whole society and from the author's point of view, increased access will provide increased impact for the work and reputation for the author, him/herself. OA publishing will definitely provide means to break the publisher monopoly and release the pressures on the academic community. OA publishing aims to provide free online access to all journals in which case reader will not be asked to pay for subscription fees and therefore increase the mass audience an article can reach and thus promote further creation of knowledge. The extent of constructive discussions over issues which will contribute to establishment of fresh ideas and theories will definitely be enlarged as the communication becomes cheaper, easier and rapid over the internet.

\subsection{Open Source Knowledge (OSK) (software)}

OSK means open technical standards and open forms of technical infrastructures, network technologies, computer architectures, system software and generic drug (for more details see Hamel, 2005; Weerawarana and Weeratunga, 2004). In the case of software it means access free of charge to coded knowledge open to modification, adaptation and further innovation. This is necessary in order to prevent the formation of inefficient monopolies and possibly exorbitant economic rent. In the case of biotechnology it means access to basic biotechnological tools. OSK is the object of a political movement, particularly dedicated to free operating systems to lessen the dominance of Windows and eventually to replace it. In this area only time will tell if various technological standards that would emerge from OSK will be superior to a few but more regulated monopolistic universal standards. Free products in the area of software usually have a catch and are usually actively promoted behind the scene by powerful corporate interests. It is the case with Linux - the main competitor of Windows. A bitter judiciary dispute is now engaged between contributors to Linux, including IBM and developers of UNIX, and their distributors, including particularly SCO Inc., over who owns what in Linux (see Hamel, 2005). Therefore it is imperative not to be too naïve in this area and be careful not to fall into costly traps under the appearance of free 
products. What is bad and must be fought is the monopolised control of technical infrastructures, via proprietary knowledge, that has the power of setting standards restricting the freedom of developers and users.

We have discussed these different initiatives together, not because they are ideas of one group of persons, but rather because we recognise that these initiatives are guided by the same 'credo' namely to ensure that information is distributed freely for the good of the public. Their emergence at different times does suggest that there is a common objection to the commodification and commercialisation of information, and the strict application of the strenuous copyright and intellectual property provisions. OA would want to eliminate all the factors that inhibit the flow of knowledge from the South to the North, and vice versa. If embraced, the movement would probably expose the true level of scientific activities going on in Africa and other developing regions, as well as giving them access to those sources that have been hitherto restrictive to them. In addition, OA will strengthen the science communities of Africa, strengthen their national science systems, and very crucially expose those virile local knowledge sources, systems and methods that are yet to find their ways into the international market of ideas, often because they are believed not to meet international standards. OA will improve the global science system by demonstrating alternative strategies and techniques which already exist but are not part of the mainstream science systems, but which also yield the same result with those research executed with standard methods. OA upholds the dictum that knowledge should be a Common Heritage of man, a right that should be made available to persons. OA will address the question of digital divide, which is actually largely due to information discrimination, a situation that can be likened to apartheid since the pattern of information wealth has been observed to follow race and colour and similar path. If the developed countries are sincere about bridging the divide, then one of our first priorities will be to address the daring need of African intellectuals, namely, freeing scientific publications from undue censorship.

\section{Building OA in Africa}

Many scholars have provided an overwhelming evidence for the disparity in scientific output between the developing and already developed countries (see Cetto, 2001; Gibbs, 1995; May, 1997; Goldemberg, 1998; Riddoch, 2000). SSA has not made any significant contribution and supplied only about $0.7 \%$ during 2001, far less than India (1.9\%) and China (2\%). Although this statistics may well be a true reflection of scientific activities in Africa (Gaillard and Hassan, 2002), there is sufficient basis to suggest that part of the reasons for the low profile of scientists in Africa is the poor access to scientific publications from the developed countries, exacerbated by the institution of copyright (Tagler, 1996).

African countries scientists require access to scientific publications, which scientists all over the world are always willing to make available at no cost, in order to benefit from and also contribute to the world stock of knowledge. What Africa needs is an initiative or arrangement that will guarantee access of scientists to scientific publications irrespective of where the sources are developed. Ordinarily, one would expect that this development favours African countries; there has arisen the necessity for scientists in the developed world to agitate for free access to scientific publications. In the recent years, several initiatives have been developed to tackle the problem of disentangling scientific 
publications from the aprons of the commercial publisher. What follows hereafter is a brief overview of these initiatives; undertaken because of the perceived low awareness and benefits they could offer to scientists.

\section{How do we build OA in Africa?}

This is a crucial question that must be answered if the strategy of OA will benefit African scientists. Currently, all OA initiatives are characterised by construction of websites containing resources which scientists are expected to use. In the absence of deliberate and organised efforts by communities in Africa, it will yet be proved whether the strategy of 'build it and they will use it' will suffice in making the movement vibrant. Moreover, participation in the OA would require constructing websites for their journals, a luxury many African journals might be able to afford now.

There is a need for a global community of stakeholder groups - librarians, authors, etc. - who will come together to champion the course of OA. This is not a difficult task; internet will easily facilitate the connection of all stakeholders. To champion this, the role of non-profit foundations at global and national levels will spawn the boost of OA. There exist sufficient clout in some world information bodies and international organisations such as the UN bodies, which promote information activities research, they could develop and nurture such foundations. These bodies seem to be committed to disseminating information widely in the DCs (Moller, 2004).

Moreover electronic publishing in most SSA countries is not only seen as an opportunity but as a challenge, despite persistent problems of infrastructure, connectivity, resources, etc. Indeed, it has been recognised by scholars in these countries as an interesting and powerful tool to overcome some of the weaknesses of local journal publishing (Cetto, 2001).

\subsection{Opportunities}

Online knowledge has distorted geography by shrinking distances and removing access barriers. Networking (subscribing to focused knowledge content), Specialised Forums, Interest Groups and e-Conferences offer extraordinary means for knowledge transfer and partnership. In a recent paper by UNECA, Hamel (2005) argues that online or e-knowledge is the best thing ever to happen to African nations. Indeed, internet provides a bonanza of knowledge. It is the new revolutionary instrument for accessing knowledge. Knowledge portals and online knowledge searching and knowledge sharing have grown fast and have considerably broken the isolation of most DCs. Weerawarana and Weeratunga (2004) argue that DCs in particular, with the resource constraints they face, view open source as a means of reducing the cost of IT investment and increasing its productivity. The imperative to adopt open source in these countries particularly in the public sector is also motivated by a desire for independence, a drive for security and autonomy and a means to address intellectual property rights enforcement.

Scientists in SSA countries can now freely access hundreds of scientific and professional journals, papers, documents, encyclopaedias, reports, presentations, lectures, etc. This represents a considerable progress in comparison with the situation prevailing only a few years ago. There is also presently an opportunity for African scholars to deposit their journals in the Directory of Open Access Journals (DOAJ), a project of Land University Libraries, Sweden as well as other OA archives. There are further 
opportunities for African journal publishers to join organisations such as Bionline, which provides access to research journals produced in Africa through the DOAJ. However, Moller (2004) has shown that despite these noble opportunities, many countries in Africa are yet to utilise the privilege offered by these resources to internationalise their research sources, except for a few that include Kenya, South Africa, Uganda and Zimbabwe.

However still today, the electronic and print versions of journals are not necessarily equivalent, and there are good reasons for making them different. According to Cetto (2001) most actors in the world of scholarly documentation (authors, editors, librarians and readers) seem to agree that the printed copy is still useful and should be kept for a long period of time (if not forever), whilst the electronic version has become essential and should be used also to develop new services for end-users. However there are several successful examples/initiatives (see Table 2) that demonstrate such opportunities for SSA countries (also see United Kingdom House of Commons Science and Technology Committee, 2004; Hamel, 2005; The Wellcome Trust, 2003 for more details and examples).

Table 2 Examples of OA initiatives in SSA

\begin{tabular}{ll}
\hline Example (Name) & Activities \\
\hline Health Inter-network Access to Research & $\begin{array}{l}\text { Provides free or nearly free access to the major } \\
\text { Initiative (HINARI) }\end{array}$ \\
& $\begin{array}{l}\text { journals in biomedical and related social } \\
\text { sciences to public institutions in SSA. }\end{array}$ \\
& (2003) Sponsored by the Food and Agriculture
\end{tabular}

Agriculture (AGORA)

International Network for the Availability of Scientific Publications (INASP)

Biological Innovation for Open Society (BIOS)

African regional ePol-Net node

NEPAD ICT Task Force, Africa

e-Commission, and the African Information Society Initiative (AISI)

West African Telecommunications Regulators Association (WATRA)

Monetary Community of Central Africa (CEMAC)

Association of Regulation of Information and Communications of Eastern and Southern Africa (ARICEA)
Organization of the UN to provide access to more than 400 key journals in food, nutrition, agriculture and related biological, environmental and social sciences.

(2002) Cooperative network of partners aiming to improve worldwide access to information.

Established with a US\$1 million grant from the Rockefeller Foundation, to make research tools more readily available to biologists who could not otherwise afford them (see SciDevNet).

(2003) Set up by UNECA with the support from Industry Canada to channel demand from African institutions and individuals, such as policy experts, programme managers and legislative drafters seeking e-strategy expertise.

Set up to develop the National Information and Communication Infrastructure (NICI).

Serves as a consultative and collaborative body and structure for the regulation of telecommunications delivery.

Serious consideration of ICT as a force in their regional integration programme.

Formed by members of the Common Market for Eastern and South Africa (COMESA) to coordinate, deliver, improve and harmonise the ICT sectors. 
Table 2 Examples of OA initiatives in SSA (continued)

\begin{tabular}{ll}
\hline Example (Name) & Activities \\
\hline African Agricultural Technology & Another example to remove many of the \\
Foundation (AATF) & barriers that have prevented smallholder \\
farmers in Africa from gaining access to & existing agricultural technologies that could \\
& help improve food security and reduce poverty. \\
& (1999) Developed under a World Bank project \\
african Virtual University (AVU) & virtual university organisation presently \\
& consisting of seventeen African countries, with \\
& its headquarters in Nairobi, Kenya.
\end{tabular}

University Twinning and

Networking (UNITWIN)

Cisco Networking Academy/UNDP

World Health Organisation (WHO) Free Medical Journals Initiative
A UNESCO programme serves as a prime means of capacity building through the transfer of knowledge and sharing in a spirit of solidarity with and between DCs.

Education and Business partnership developed with some academic institutions in Africa and award educational certificates and degrees (Namibia, Mali, Malawi, Mozambique, and Nigeria).

(2001) Provides free (or at drastically reduced cost) electronic access to nearly 1000 medical journals to developing nations including most of SSA countries. The initiative benefits nearly 600 institutions, including medical schools, research laboratories and government health departments. The programme also offer training to enable researchers to properly access the medical information by computer.

(2001) To post virtually all of the course materials from MIT classes for free on the internet to students and college faculty in DCs.
Massachusetts Institute of Technology (MIT) Free Course Materials

Notes: Global markets, global technology, global ideas and global solidarity can enrich the lives of people everywhere. The challenge is to ensure that the benefits are shared equitably and that this increasing interdependence works for people - not just for profits.

Sources: UNDP Human Development Report (1999)

United Nations Development Programme, Globalisation with a

Human Face, UNDP Human Development Report, tenth edition,

Getty Center for Education in the Arts, Washington, DC (1999)

\subsection{Challenges and threats}

There is a serious concern that electronic resources are inaccessible to SSA countries as they simply do not have the technological infrastructure to receive and distribute them effectively. Key issues at the higher institutional level include: regulatory challenges of the telecommunications and IT policies, human resource development factors, the question of quality assurance, among others. Further studies are required to gauge the way in which these factors constrain the range of OA options available to Africa, and how to overcome them. 
We can also observe from the foregoing that many African countries, which ought to be the prime beneficiaries of OA, have not actually addressed the movement. Even at the individual institutional level, adequate concern about access to institutional publications have hardly been expressed. Except in South Africa where the University of Western Cape has launched an Open Content project, we have not identified any other identifiable institutional Open Content initiative. All the efforts aimed at liberalising access to scientific publications originate from either US or UK, comprising both government and non-government agencies and associations. Initiatives from association of libraries, association of provosts, among other high-ranking calibre of scientists as seen in the developed countries are not yet identifiable in Africa.

We can suggest that editors of local journals might be preying on the relative non-existence of Western competition to sell their though irregularly and low quality journal products, and thus play non-challance to the problem of access of scientific papers of scientists. Significant scholarship in OA is not even identifiable. Conventional wisdom would have prevailed upon library, information and social scientists to embark on studies that could generate debates on why African scholars deserve an uncopyrighted access to scientific papers of the developed countries. Rather, it would appear that African scholars are satisfied with coping mechanisms, in which retrospective and back-number journals are bequeathed to their scientists by retiring scholars from the North or by some form of benevolence of DCs' institutions and international agencies.

The dangerous consequences of this negligence for further isolation of Africa and its scientists are not obvious now. But one can learn serious lessons from the internet revolution. African countries started participating and initiating programmes to make contribution to, and in the governance of the, Net in the later part of the 1990s with the consequence that there is today little African influence in the internet at all levels (Nwagwu, 2005). There is no assurance that the Open Content initiatives being championed by Western scholars and associations will ultimately serve the benefit of the Southern scholars. There could be, for instance, peculiar policy positions and requirements from the DCs, which could make the initiatives serve the purpose and meet the needs of their countries' scholars better. But such positions cannot obtain except African scholars express consciousness about the negative impact poor access of scientific content can be filled by deliberate actions. We can spot this same attitude in different aspects of the efforts being made by different communities to reap from the wealth of the present the electronic revolution era. For instance, the question of digital preservation, namely the identification and retainment of appropriate information originally created digitally without any paper counterpart, is not yet addressed. Some electronic journals are presently available at no cost. If the current observed pattern in which such journals first capture their audience and then expect them to subscribe in order to have continued access is a good signal, and if the library of the future is believed to be digital, then it would be right to expect Africa countries to start addressing the problems of digitisation, and other related issues. It is only in this way that Africa would have a reservoir of usable knowledge that could be bought by scientists from other regions. As a matter of fact, the effort of developed countries to free scholarly publications from the stranglehold of the publisher and to enhance the wider dissemination of scientific articles free of charge, can be considered a largesse the African scientists and science communities should grab. 
Almost all SSA countries face many strategic challenges and serious concern that online sources (e.g., digital journals) are inaccessible as they simply don't have the technological infrastructure to receive and distribute them effectively. Weak communication and social infrastructure not only block information flows in most SSA countries but ultimately stifle social and economic development.

There are also other issues related to the pattern of access to the resources of the internet and other ICTs (Chisenga, 1999). Weerawarana and Weeratunga (2004) argue that the critical factor for open source and OA publishing is the ability to become part of the internet as their development occurs primarily via e-mail communication and shared repositories published on the internet. Despite having a very rapid rate of internet penetration, Africa still lags behind in internet connectivity (Keats and Beebe, 2003) with barely $1 \%$ of internauts are in Africa and the Middle East. This point is very crucial because much of the efforts to free scientific publications from the publisher in the electronic revolution are the internet facilities. Scientists who are not connected to the internet are excluded automatically from publishing in, and benefiting from, a growing number of journals, because many new journals are created online while many old ones now often have online counterpart. Also we should not forget that internet connection still requires a telephone line, and at least $80 \%$ of the world population does not have access to one.

There is hype about the tendency of the internet and other ICTs to reduce the reliance on paper and other printed resources for scientific communication, and the consequent expectation of reduction in the prices of such media. At the beginning of the era of ICTs revolution, there were speculations that the differences in information access between the developed countries and those from Africa would be obliterated. But publishers now even develop information warehouses; franchise electronically published resources and makes them available only to fee-paying subscribers, thus creating new forms of problems in the economics of serials. Electronic publications, which once seemed to be capable of ending the isolation of African scholars, are presently as exorbitant and difficult to access as their printed-paper counterparts. Subscription costs are very high coupled with stringent conditions for their use and sharing. For instance, certain conditions for subscription and use of electronic resources sometimes, require that the subscriber should not share the resources with other non-subscriber users. This condition seems to be observed by moralist information consumers who also wish to maintain good relationship with their information suppliers. A library belonging to an old member of faculty or a library of a big institution unwanted printed resources, and old publications can be bequeathed to other persons or institutions. In the electronic era, this kind of expectation is actually made difficult by the fact subscription conditions sometimes restrict the use of published materials to the institution or individual who pays the subscription fee. There are also concerns that the financial constraints on widespread use of the internet are also evident. In most African countries, university authorities give restricted net access to heads of department or senior staff via shared terminals "because dial-up access is expensive" (Lund, 1998).

Cetto (2001) adds other obstacles and constraints that make of electronic archiving and preservation of scientific material a still unresolved issue, such as: the non-existence of some relevant titles in electronic form, the lack of technical support and reliable 
electronic infrastructure, and the uncertainty faced by libraries and end-users about future access - even to previously paid subscriptions. Under such circumstances, the transition from the paper to the digital world sounds as hardly realistic.

In a networked world, the opportunity cost and risk for an African country lacking sophisticated IT capabilities and means of effective interaction with the global economy could be substantial, with growth and development being seriously affected (Weerawarana and Weeratunga, 2004). Thus, decisions governments make relating to IT strategy and policies broadly, and in particular to procurement, the setting and adoption of standards, investment in technology, and training and skill development can have grave consequences for the future well being of their peoples. Moreover, ICTs used are by their very nature, cultural. As noted by Keniston (1998); the content of software is determined not only by the language, but by deep, underlying, usually implicit and unacknowledged (because thought to be natural) assumptions inherent in the software itself. Software carries with it a view of the world, of people, of reality, of time, of the capabilities of users, which may or may not be compatible with any given and social context.

Presently the ICT era is yet to be universalised, and this cannot obtain except all the languages of the world digitalised. Presently, African languages, for instance, are yet to make any meaningful input in the internet. As is well known, the internet is overwhelmingly US-based, English speaking, and Western-focused. As at June 2005, roughly $73 \%$ of the estimated 72.4 million host computers are in the USA, $80 \%$ in English-speaking nations and more than $90 \%$ of the internet operated out of Western countries (ISC, 2000). As to the online language populations, in May 2005 English language dominated with $35.2 \%$, followed by Japanese with $13.7 \%$ and Spanish $9.0 \%$ (GIS, 2005). These distributions are very different from the distribution of languages around the world, in which population-wise is dominated by Chinese in the first place, followed by English and further by Spanish in the third place. Of course, the distribution of languages in science is again very different, English being by far the dominating one. The uneven use of local languages in science is of course not exclusive of the internet, but is only being epitomised by it. More generally, the loss of linguistic and cultural diversity that is occurring among social systems is exacerbated by technical systems. Among colleagues and peers, there has been a gradual acceptance of the use of English as lingua franca and, at least, for the foreseeable future, there is little reason to expect any change in this trend.

Furthermore the lack of Intellectual Property (IP) law framework and enforcement is common symptom in most SSA countries as many countries simply failed to enforce IP laws. The result of course has been rampant pirating of proprietary software, thereby creating a false reality of wide availability of proprietary products at no cost. For example, it is common for a new computer to be pre-installed with pirated copies of whatever proprietary software the customer wants. In addition to being illegal, such piracy devalues the economic benefits of open source products by falsely reducing the price of proprietary software. The economic benefit of open source products will not be felt until IP is properly protected (see Weerawarana and Weeratunga, 2004 for more details).

Another challenge in most SSA countries is issues regarding Freedom of Information. Access to the internet brings with it free access to information and therefore if the political climate of the country does not permit such access (most SSA countries), then open source cannot succeed in that country. 
Furthermore certain requirements and conditions need to be met in order for open source activities to proceed down a strategic path such as funding, ICTs infrastructure and skills, and individual and institutional involvement (World Bank, 2000a-b; 2001; 2003a-b; 2004; 2005; Weerawarana and Weeratunga; 2004).

Financial constraints over funding free online publishing have been threatening the feasibility of the OA. Tola (2003) suggests that poor countries should be guaranteed the right to have free access to scientific publications in order to slow down the asymmetric scientific development between developed and DCs. However, this right has recently been denied mainly because of the increasing subscription costs. Building on OA in Africa will require investment by national governments because of the expected huge financial requirements of designing of tools, providing platforms for management and making the technology available. Moreover, there has always been the fear that left to the market forces alone, private organisations might not be willing to invest in scientific databases since research is always a long-term investment, with unpredictable returns. Also, the 'free rider' and 'public good' status of information for which it is quantifiable only in terms of publications seem to make information a superficial good (see Folster, 1988). According to the World Bank, the private sector invested \$230 billion in telecommunication infrastructure in developing world between 1993 and 2003 (The Economist, 2005, p.9).

\section{Conclusions}

In this article, we have taken a somewhat extensive review of the different aspects of the digital divide and OA in DCs with particular focus on SSA. While the digital divide has been recognised as a threat to the expected global economy, the pattern of scientific activities tends to show that we might end up with entering a new Dark Age, unless we redesign an information-oriented democracy in the 21st Century. The absence of the expectation that information should flow in and out of Africa and other developing regions, a true global economy cannot be realised since the global economy rides on the wheel of information. Whatever might emerge as a global economy will be skewed in favour of the information-haves, leaving behind the rich resources of Africa and other regions, which are often regarded as information have-nots. As a matter of fact, the current pattern of the globalisation process is leaving something very crucial behind, namely the multifaceted intellectual 'wealth' and 'natural resources' of Africa. As a matter of fact, the beauty of a truly globalised world would lie in the diversity of the content contributed to the GII by all country members of the world. A less than multi-coloured global community would have omitted variety and diversity, and such a community cannot be considered truly global.

The need to ensure a free flow of scientific articles should therefore be pursued by DCs (particularly SSA) with vigour. African countries should as a matter of priority adopt collaborative strategies with agencies and institutions in the developed countries where research infrastructures are better developed, and where the quest for access to scientific publication is on the increase. African scholars should also identify with movements aimed at liberating scholarly articles from undue control of agencies that have commercial intentions. The methodology for this identification could be by forming local movements, which will then seek liaison with those in the developed world. Very 
importantly, effort to enhance access to scientific publications should start locally. Even within an institution in most African countries, access to articles written by scientists is very scant. Local institutions should initiate local literature control services with the sole aim of making the content available to scientists. If properly initiated, institutions can then network with each other so that within a given country, access to scientific publications can be eased. Such an initiative has been ongoing in Nigeria under the aegis of the National University Commission's NUNet Project but a more serious examination of the strategy and content of this network can only be carried out as the result of this undertaking, which can be considered protracted, begins to manifest.

Governments' support is necessary in SSA countries to build the required infrastructure for OA. Also research oriented institutions should be able to grant some funds to offer free access to their readers. This model can be realised feasible in the sense that governments already pay large sums for R\&D and OA model can be seen as an extension of R\&D investments for transferring the outcomes of the conducted research to the society. Institutions should also be willing to contribute to the financing of the model as they already pay subscription fees for their readers in larger amounts.

\section{References}

African Tertiary Institutions Connectivity Survey (ATICS) (2005) 'African Virtual University (AVU)', Nairobi, http://www.atics.info/index.html (accessed on 19 March 2006) also see http://www.avu.org.

Ahmed, A. (2004) 'Making technology work for the poor: strategies and policies for African sustainable development', Int. J. Technology, Policy and Management, Vol. 4, No. 1, pp.1-17.

Ahmed, A. and Nwagwu, W. (2006) 'Challenges and opportunities of e-learning networks in Africa', Development, Vol. 49, No. 2, pp.58-64.

Anyimadu, A. (2003) 'Being digital by default', Paper Presented during the International Conference on Electronic Publishing and Dissemination Organized by Council for Development of Social Science Research in Africa (CODESRIA) held from 1-2 September 2003, www.codesria.sn.

Arunachallam, S. (2002) 'Reaching the unreached: what role can ICTs play in rural development?', Paper Presented at the Asian Regional Conference of UN ICT Task Force - Media Lab Asia, New Delhi, 25 April.

Castells, M. (1998) End of Millennium, Oxford: Blackwell.

Cetto, M.A. (2001) 'The contribution of electronic communication to science - has it lived up to its promise?', Proceedings of the Second ICSU - UNESCO International Conference on Electronic Publishing in Science, UNESCO House, Paris, 20-23 February.

Chisenga, J. (1999) 'Global information infrastructure and the question of African content', Paper Presented at the International Federation of Library Associations (IFLA) 65th Annual Conference, www.ifla.org/IV/ifla65/papers/118-116e.htm (retrieved on 13 June 2005).

Create Change (2000) 'Scholars under siege', http://www.createchange.org/librarians/issues/ silent.html (retrieved 14 June 2005).

Danofsky, S. (2005) 'Open access for Africa: challenges, recommendations and examples', United Nations ICT Task Force Working Group on the Enabling Environment, The United Nations Information and Communication Technologies Task Force, New York, USA.

De Solla Price, D.J. (1963) Little Science, Big Science, New York: Columbia University Press.

DiMaggio, P., Hargittai, E., Neuman, W.R. and Robinson, J.P. (2001) 'Social implications of the internet', Annual Review of Sociology, Vol. 27, pp.307-336. 
Dutton, W.H. (1997) Information and Communication Technologies: Visions and Realities, New York: Oxford University Press.

Dutton, W.H. (1999) Society on the Line: Information Politics in the Digital Age, New York: Oxford University Press.

Folster, S. (1988) 'The incentive subsidy for government support of private support of R\&D', Resaerch Policy, Vol. 17, pp.105-112.

Gaillard, J. and Hassan, M. (2002) 'Africa: UNESCO science report', http://knowledge.cta.int/en/content/view/full/1197 (retrieved 13 June 2005).

Gibbs, W.W. (1995) 'Lost science in the third world', Science in America, Vol. 273, pp.92-99.

GIS (2005) 'Internet world statistics', http://global-reach.biz/globstats/index.php3 (retrieved 5 May 2005).

Goldemberg, J. (1998) 'What is the role of science in DCs?', Science, Vol. 279, pp.1140-1141.

Hamel, J.L. (2005) 'Knowledge for sustainable development in Africa towards new policy initiatives', World Review of Science, Technology and Sustainable Development, Vol. 2, No. 3, pp.217-229.

Hefter, L.R.H. and Litowitz, R.D. (2005) 'What is intellectual property? United States information program', http://usinfo.state.gov/products/pubs (retrieved 5 May 2005).

ISC (2000) 'Internet software consortium: internet domain survey', http://www.isc.org/ds/ (retrieved 5 May 2005).

Juma, M.N. (2003) 'The African virtual university. Challenges and prospects', in M. Beebe, B.O. Oyeyinka, K.M. Kouakpou and M. Rao (Eds.) AfricaDotEdu. IT Opportunities and Higher Education in Africa, New Delhi: Tata McGraw Hill.

Keats, W.D. and Beebe, M.A. (2003) 'Using technology to enable universities meets the challenges of globalization through collaborative virtual programs', South African Journal for Research and Development in Higher Education, Vol. 16, No. 2, pp.1-15.

Keniston, K. (1998) 'The politics of copyright', Economic and Political Weekly, 17 January, Mumbai, India.

Lund, H. (1998) 'Bridging the gap?', Commonwealth Higher Education Management Service, September.

Mansell, R. and When, U. (1998) Knowledge Societies: Information Technology for Sustainable Development, UN Commission on Science and Technology for Development, New York: Oxford University Press Inc.

Marcelle, G.M. (2004) Technological Learning: A Strategic Imperative for Firms in the Developing World, Cheltenham, UK: Edward Elgar Publishing Limited.

May, R.M. (1997) 'The scientific wealth of nations', Science, Vol. 275, pp.793-796.

Mengxiong, L. (1993) 'Progress in documentation, the complexities of citation practice: a review of citation studies', Journal of Documentation, Vol. 49, No. 4, p.409.

Merton, R.K. (1973) The Sociology of Science, Chicago, IL: University of Chicago Press, p.605.

Moller, A. (2004) 'The rise of open access journals: their viability and their prospects for the African scholarly community', Paper Presented during the International Conference on Electronic Publishing and Dissemination Organized by Council for Development of Social Science Research in Africa (CODESRIA) held from 1-2 September 2003, www.codesria.sn (retrieved 13 June 2003).

Nulens, G., Hafkin, N., Van Audenhove, L. and Cammaerts, B. (2001) The Digital Divide in DCs: Towards an Information Society in Africa, United Nations Economic Commission for Africa (UNECA), Studies on Media Information and Telecommunication (SMIT), VUB, Brussels: University Press.

Nwagwu, W. (2005) 'Deficits in the visibility of African scientists: implications for developing Information and Communication Technology (ICT) capacity', World Review of Science, Technology and Sustainable Development, September, Vol. 2, Nos. 3-4. 
Riddoch, I. (2000) 'Bridging the quality gap', Nature, Vol. 408, p.402.

Stallman, R.M. (1999) 'The GNU operating system and the free software movement', Open Sources, Voices from the Open Source Movement, California: O'reilly.

Tagler, J. (1996) 'Recent steps toward full-text electronic delivery at Elsevier Science', The Serials Librarian, Vol. 28, Nos. 1-2, pp.171-179.

The Economist (2005) The Real Digital Divide, London, UK, 12-18 March, Vol. 374, No. 8417 , p.9.

The Wellcome Trust (2003) Economic Analysis of Scientific Research Publishing: A Report Commissioned by the Wellcome Trust.

Tola, E. (2003) 'Hinari and Agora: free access to scientific information for poor countries', Journal of Science Communication (JCOM), December, Vol. 2, No. 4, ISSN: 1824-2049, http://jcom.sissa.it/focus/foc020403_or.html.

United Kingdom House of Commons Science and Technology Committee (STC) (2004) 'Scientific publications: free for all?', Tenth Report of Session 2003-04, Volume I: Report, HC 399-I, London: The Stationery Office Limited, http://www.publications/parliament.uk/pa/cmselect.

United Nations Conference on Trade and Development (UNCTAD) (2003) E-Commerce and Development Report, UN, New York and Geneva.

United Nations Development Programme (UNDP) (1999) 'New technologies and the global race of knowledge', Human Development Report 1999.

United Nations Development Programme (UNDP) (2004) 'Human development report 2004', Cultural Liberty in Today's Diverse World, http://hdr.undp.org/statistics/data/indic/ indic_115_3_2.html.

United Nations World Summit on the Information Society (2003) 'Declaration of principles and plan of action', http://www.itu.int/wsis/documents/doc_multi.asp?lang=en\&id=1161|1160.

Vinay, K. and Saran, R. (1998) 'The best cities 1998', Business Today, 22 December, Living Media India Ltd.

Walsham, G. (2000) 'IT/S in DCs', in M. Zeleny (Ed.) The Handbook of Information Technology in Business, International Encyclopedia of Business Management, London, UK: Thomson Learning, ISBN: 1-86152-308-4, pp.105-109.

Weerawarana, S. and Weeratunga, J. (2004) 'Open source in DCs', The Swedish International Development Cooperation Agency (SIDA), ISBN: 91-586-8613-4, http://www.sida.se/ publications.

Wiley, J. (1999) 'Open publication license', http:/Open content.org/openpub (retrieved 13 June 2005).

World Bank (2000a) African Development Indicators, Washington, DC: World Bank.

World Bank (2000b) Can Africa Claim the 21st Century?, The International Bank for Reconstruction and Development, Washington, DC: World Bank.

World Bank (2001) World Development Report 2001: Attacking Poverty, Washington, DC: World Bank.

World Bank (2003a) Global Economic Prospects: Realizing the Development Promise of the Doha Agenda, The International Bank for Reconstruction and Development, The World Bank, Washington, DC: World Bank.

World Bank (2003b) World Development Indicators (WDI) 2003, Washington, DC: World Bank.

World Bank (2004) World Development Report 2004: Making Services Work for Poor People, Washington, DC: World Bank.

World Bank (2005) World Development Report 2005: A Better Investment Climate for Everyone, Washington, DC: World Bank, http://publications.worldbank.org/ecommerce/catalog/ product?item_id=3043503. 


\section{Bibliography and websites}

Berlin Declaration on Open Access to Knowledge in the Sciences and Humanities, http://www.zim.mpg.de/openaccess-berlin/berlindeclaration.html.

Bethesda Statement on Open Access Publishing (2003) http://www.earlham.edu/ peters/ fos/bethesda.htm.

International Telecommunications Union Different Reports.

Internetworldstats (2004) Internet usage statistics - the big picture (worldinternet users and population statistics, January 2005).

Joint Information Systems Committee, http://www.biomedcentral.com/.

Peter Suber. Timeline of the Open Access Movement, http://www.earlham.edu/ peters/fos/ timeline.htm.

Public Library of Science (PLoS) www.plos.org.

Science and Development Network (SciDevNet), http://www.scidev.net/news/index.cfm? fuseaction $=$ readnews $\&$ itemid $=1636 \&$ language $=1$.

The Welcome Trust (2004) 'Costs and business models in scientific research funding', http:/www.welcome.ac.uk/en/images/costs_business.7955.pdf (retrieved 5 December 2004).

United Nations Economic Commission for Africa (UNECA) (2003) E-Strategy, Addis Ababa, Ethiopia.

UNESCO (1997) 'Revised outline of a (UNESCO) declaration on the protection of the human genome', http://www.biol.tsukuba.ac.jp/ macer/EJ54M.html (retrieved 23 May 2005).

United Nations (2002) 'Implementation of the United Nations millennium declaration', Report of the Secretary-General, United Nations General Assembly, http://www.un.org.

United Nations Educational, Scientific and Cultural Organization (UNESCO) (1992) UNESCO Statistical Yearbook 1991, Paris: UNESCO.

United Nations Educational, Scientific and Cultural Organization (UNESCO) (2001) The State of Science and Technology in the World, UNESCO: Institute of Statistics.

United States Congress Public Access to Science Act, http://thomas.loc.gov/cgi-bin/query/ z?c108:H.R.2613.

\section{Notes}

1 International bandwidth in bits per capita is the new measure of internet use, shows how a country is progressing towards an information-based economy.

2 A property owner is one who originated and developed the property in question. But an antithesis in this development is that publishers have arrogated right of ownership of intellectual properties to themselves instead to the originator of the property. In the academic circles, this antithesis could be very serious (Hefter and Litowitz, 2005).

3 The idea of Open Content formed by David Wiley, a doctoral student at Brigham Young University in the USA. 